\section{induced-fit 機構}

Koshland の「induced-fit」説は酵素反応を次のように 説明する。基質を取り込んでいないフリーの酵素の活性 部位は, 最適基質の取り込みに伴ってその結合エネル ギーによりコンホメーション変化を起すが, これは酵素 タンパク自体にとってはエネルギー損失をもたらす。し かし，触媒基は最大活性を発現する配置をとるようにな る。非特異的基質の場合にはコンホメーション変化を起 しても触媒基配置について最適化ができない。この概念 はホストーゲスト化学における分子認識機能に適用でき る。本号掲載の「シクロファン」に関する小文で述べてい る「タコ」型シクロファンについていえば, シクロファン 環に結合した 8 本のアルキル長鎖は一方の末端が固定さ れていないため, ゲスト分子不在の時にはアルキル長鎖 間の疎水性相互作用により，ある種の集合状態をとる。 ゲスト分子の取り込みに伴ってその結合エネルギーはア ルキル長鎖のコンホメーション変化を誘起するが, その 変化の様態，いいかえればアルキル長鎖の広がり具合は ゲスト分子の形状およびかさ張り程度によって異なって くる。これがここでいう「induced-fit」機構の理念である。

（村上幸人）

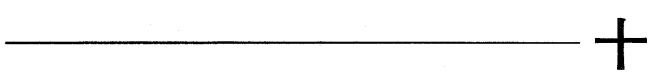

クリプタンド, キャピタンド, スフェランド, カルセ ランド (Cryptand, Cavitand, Spherand, Carcerand)

1967 年の Pedersen によるクラウンエーテルの報告以 来, あらゆる種類の大環状ポリエーテル類が開発されて きた。それらは構造が複雑で, 正式な命名法では記述が 困難なため，一般的には開発者の命名した慣用名が用い られることになる。ポリエーテル系の化合物に関しては， 化合物のトポロジーに基づいた分類がなされている (Vögtle, 1980)。それによると, 鎖式化合物は “podand”, 環式化合物は “coronand”, 複環式化合物は “cryptand” と総称される。酸素原子のみを配位子としてもつ coronand には crown の名称が残された。これらのホストと ゲストとの錯体は, 接尾語 “ate”を用いて, “podate”, “coronate”, “cryptate”のように表記することが提案さ れている。分類名として採用された cryptand は, Lehn (1969) が $\mathrm{N}$ を橋頭にもつ双環式化合物に命名したもの で，ギリシャ語由来の crypt (隠された，あなぐら）に因 んでいる。

クラウン化合物やクリプタンドは錯形成に伴って内孔 が形成されるが, Cram らは錯体の生成, 解離の過程で 内孔のコンフォーメーションの変化しないホストを開発

\section{キャップ試薬}

シクロデキストリン $(\mathrm{CD})$ の二置換体には, 多種類の 異性体が存在する。グルコースが 7 個からなる $\beta-\mathrm{CD}$ の グルコース単位を順番にC-6 位側から見て反時計周り に $\mathrm{A}, \mathrm{B}, \mathrm{C}, \cdots \cdots$ とすると, 二ヶ所のC-6 位水酸基を 同じ置換基で修飾しても $\mathrm{AB}$ 体, $\mathrm{AC}$ 体, $\mathrm{AD}$ 体, の三 種類の異性体が存在する。これらの異性体を選択的に合 成する目的で開発されたのがキャップ試薬である。 キャップ試薬は, 硬直なスペーサーの両末端にスルホニ ルクロリドを有する化合物であり，渡環的にC-6 位水 酸基の二ヶ所をスルホニル化することが出来る。そして, スペーサーの構造を変えることにより異性体の何れか一 つを選択的に合成することができる。例えば，transstilbene-4,4'-disulfonyl chloride を用いることにより， $\beta-\mathrm{CD}$ の $\mathrm{AD}$ の位置を選択的にジスルホニル化すること が出来る。得られたジスルホニル体は capped CD と呼 ばれており，合成中間体として利用することにより， $\mathrm{CD}$ の目的の位置に官能基を導入することが出来る。

（池田 博, 戸田不二緒）

\section{路}

した。予めデザインされた強固な内孔 (cavity)を持つホ ストはキャビタンド (cavitand) と総称された。キャビタ ンドの中で, 配位子の形成する内孔が球 (sphere) 状のホ ストはスフェランド (spherand) と呼ばれている。キャビ タンドをお椀を閉じるように二量化させると, 強固な内 孔で挾まれた閉じた空間が構築される。このように牢獄 (carcer)のような空間を持つホストはカルセランド (carcerand) と名付けられた。Cram はこのようにホスト の特徵を示す単語に接尾語 “and”を付けて化合物名と している。またこれらのホストの形成する錯体はコンプ レックス (complex) とおなじ接尾語“plex”を付けて,キャ ビタプレックス (cavitaplex), スフェラプレックス (spheraplex), カルカプレックス (carcaplex)などと呼ぶ ように提案している。本文に紹介したように,これらの ホストは酵素の活性部位と同様の三次元的な閉じた空間 を構成することができ，これまでにない興味深い機能を 発揮する可能性が期待されている。

（佐々木茂貴，古賀憲司） 
ワトソンークリック型水素結合とフーグスティーン型水 素結合

通常の DNA は 2 重らせん構造をとるが, これはアデ ニン $(\mathrm{A})$ とチミン $(\mathrm{T})$ ，シトシン $(\mathrm{C})$ とグアニン $(\mathrm{G})$ 塩基 が各々特異的な水素結合を形成するためである。 $\mathrm{C}$ と $\mathrm{G}$ の間には，1)Cの N4-H と GのO 6, 2)Cの N3と Gの N1-H，3)CのO 2 と Gの N2-H の 3 本, $\mathrm{T}$ と A との間に は, 1) T の O 4 と A の N6-H, 2) T の N3-H と A の N 1 の 2 本の水素結合がある。DNAの 2 重らせん構造の発 見者であるWatson, Crickによって初めて提唱された ので，ワトソンークリック型水素結合と呼ばれる。

これに対し，極く稀な場合には，A や G のグリコシル 結合まわりのねじれ角が通常の anti から syn 型に変わ り, その結果, A-T 対では T の N3-H と A の N 7 との間 に水素結合ができる。これを，最初に記述した Hoogsteen の名をとって，フーグスティン型水素結合と呼ぶ。 この他に, 逆フーグスティン型塩基対もある。

(黒田玲子)

\section{$A ， B$ 型 DNA と Z 型 DNA}

DNA 分子の高次構造の種類。DNA 分子は 2 重らせん 構造をとるが, 水溶液中では通常 $\mathrm{B}$ 型といわれる形をと る。この形ではらせんの 1 ピッチに 10 ヌクレオチド残 基があり，塩基対はらせん軸に垂直であり，塩基対の中 心はらせん軸とほぼ一致している。ところが, DNA 緎 維を相対湿度が $85 \%$ 以下の環境に置くと, A 型に変わ る。A 型では, らせんの 1 ピッチに 10.7 ヌクレオチド 残基あり, 塩基対平面はらせん軸に垂直な平面から $19^{\circ}$ も傾いている。塩基対の中心はらせん軸からかなりはず れている。そのため，らせん軸のまわりには空洞ができ， らせんはB型よりも太めである。

$\mathrm{A}, \mathrm{B}$ 型ともに右巻きのらせんであるが, プリンーピ リミジンが交互に並ぶ塩基配列をもった DNA は, 高塩 濃度水溶液中では, ジグザグした左巻きの $Z$ 型 DNA と なる。12 クレオチド対がらせんの 1 巻きを作り， 2 又ク レオチド対が繰り返しの単位を形成している。実際の DNAの高次構造は, 典型的 A, B, Z 型ではなく, 塩基 配列によって微妙な局所構造をとる。

（黒田玲子）

ロンドン分散カ

1930 年にF.London によって量子力学的に導入された 分子間引力・無極性分子にも働く力で, ヘリウム, アル ゴンのような希ガス気体間に働く分子間引力を説明する ものである。

古典的には以下のように説明する。電気的に中性かつ 無極性の原子, 分子であっても, 電子運動に伴って時間 とともに変化する電場が生じ，ある瞬間には自発的双極 子が生ずる。これが近接する他の原子, 分子に誘起双極 子を引き起こし, 両者の間に引力が生ずる。量子力学的 には，この力は両分子の電気モーメントの間の力を演算 子とする 2 次拱動エネルギーとして与えられる。原子や 分子による電磁波の分散も同じく 2 次摂動により, 分子 間力と数学的に同じ項を含むため, London は分散力と 名づけた。いわゆるファンデルワールスカのうち最も一 般的で重要なものである。

(黒田玲子) 機化合物を配位子とする錯体でもこのような例がある。

\section{字 路}

金属を $\mathrm{M}$ として，M-O-M 型の結合をもつ酸素橋かけ 複核錯体の総称で, 多くの金属についてこの型の錯体が 見い出されているが, 通常, 金属アコ錯体が塩基性条件 下で $\mu$-オキソ錯体を生成する。

$$
\mathrm{M}-\mathrm{OH}_{2} \stackrel{-\mathrm{H}^{+}}{\longrightarrow} \mathrm{M}-\mathrm{OH} \stackrel{\mathrm{M}}{\longrightarrow} \mathrm{M}-\mathrm{O}-\mathrm{M} \stackrel{-\mathrm{H}^{+}}{\longrightarrow} \mathrm{M}-\mathrm{O}-\mathrm{M}
$$

配位子については，有機・無機配位子を問わず，単純な 例では, $\left(\mathrm{NH}_{3}\right)_{5}-\mathrm{Cr}-\mathrm{O}-\mathrm{Cr}\left(\mathrm{NH}_{3}\right)_{5}^{4+}, \mathrm{Cl}_{5} \mathrm{Ru}-\mathrm{O}-\mathrm{RuCl}_{5}^{4-}$ 等 がある。一方，ポルフィリン(Por) のような大環状有 例えば，PorAl ${ }^{\mathbb{I I}}-\mathrm{OH}$ から生成する PorAl ${ }^{\mathbb{I I}}-\mathrm{O}-\mathrm{Al}{ }^{\mathbb{I I}}$ Por な どの例がある。しかしながらポルフィリンの場合 $\mu$-オ キソ錯体は, $\mathrm{PorFe}^{\mathbb{I}}$ による酸素の可逆的吸脱着機構と 関連して極めて重要である。即ちへモグロビン等のへム は酸素と $1: 1$ 錯体 $\left(\mathrm{PorFe}^{\mathrm{II}}-\mathrm{O}_{2}\right)$ を可逆的に生成するが, 通常の合成へムでは，この型の酸素錯体は $\mu^{-}$パーオキ ソ錯体を経て $\mu$-オキソ錯体へ速やかに变化する。この 不可逆な $\mu$-オキソ錯体生成を防ぐために,

$$
\begin{aligned}
& \text { PorFe }{ }^{\mathbb{I I}}-\mathrm{O}_{2} \rightarrow \mathrm{PorFe}^{\mathbb{I I}}-\mathrm{O}-\mathrm{O}-\mathrm{Fe}^{\mathbb{I I}} \text { Por } \\
& \quad \rightarrow-\stackrel{-\mathrm{H}_{2} \mathrm{O}_{2}}{\longrightarrow} \mathrm{PorFe}^{\mathbb{I I}}-\mathrm{O}-\mathrm{Fe}^{\mathbb{I I I}} \text { Por }
\end{aligned}
$$

蛋白質の機能を模してポルフィリン骨格に大きな立体障 害を付加し二量化反応を防ぐ工夫がなされている。

(生越久靖) 
ゲル-液晶相転移：Tc

固体の二分子膜化合物を加熱するとある一定温度で光 学的異方性を示す粘調な液体 (液晶相)になり, 最後に融 点に達し等方性液体となる。液晶相の二分子膜構造の局 所的な秩序性は固相のそれに比べて大きく低下する。固 相 $\rightarrow$ 液晶相と同様な相変化は二分子膜の水分散系でも認 められる。その相転移温度 $(\mathrm{Tc})$ は水の割合(結合水の生 成)に依存し， ～80 wt(水)％以上では一定となる。通常 の二分子膜水分散系の膜濃度 $\left(10^{-5} \sim 10^{-2} \mathrm{M}: 95 \sim\right.$ $99.9 \mathrm{wt}$ (水) \%)では Tc の濃度依存性はない。水分散系 の Tc 以下の相をゲルまたは結晶相と呼んでいる。ゲル 相での構成分子の配列秩序性, 流動性等は液晶相のそれ とは大きく異なる。ゲル相での疎水アルキル鎖はトラン ス構造であり，一構成成分の平均占有体積も小さい。構 成分子間の van der Waals 相互作用に基づく協同性も強 く, 発達した配列秩序性を持つが, 流動性は乏しい。こ れに対し, 液晶相の疎水アルキル鎖はゴーシュ構造が混 在し, 一成分の平均占有体積も大きい。構成成分の配列 秩序性も低下し，流動性も大きい。両相ともに二分子膜 であるがその物理化学状態は全く異なる。

(石川雄一, 国武豊喜)
強誘電性, 反強誘電性, 常誘電性

中性な分子あるいは(結晶の) 単位胞内における正負電 荷分布の中心は, 外部電界を印加しなくても, 自発的に ずれていることがある。負電荷の中心から正電荷の中心 に向い, 大きさが正電荷の総量と中心間距離との積で与 えられるベクトル量 $\boldsymbol{p}=q \boldsymbol{l}[\mathrm{C} \cdot \mathrm{m}]$ を永久 (電気) 双極子 モーメントという。分子の凝集系や結晶内の巨視的な微 小体積 $\delta V(\boldsymbol{r})$ に含まれる $\boldsymbol{p}$ のベクトル和 $\sum_{\delta V} \boldsymbol{p}$ は体積 $\delta V(\boldsymbol{r})$ に比例するので, 両者の比 $\boldsymbol{P}(\boldsymbol{r})=\sum_{\delta V}^{\delta V} \boldsymbol{p} / \delta V(\boldsymbol{r})$ $\left[\mathrm{C} \cdot \mathrm{m}^{-2}\right]$ は点 $\boldsymbol{r}$ における単位体積あたりの永久双極子 モーメントを与え, 自発分極と呼ばれる。分子や単位胞 が $\boldsymbol{p} \neq 0$ をもっていても，通常の系では $\boldsymbol{p}=0$ となる。 隣あった永久双極子が反平行に並んでそのモーメントを 打ち消し合うからである。しかし，永久双極子間の相互 作用あるいは他の構造的な原因により $\boldsymbol{P} \neq 0$ となること がある。このような $\boldsymbol{P}$ の方向, 向きを外部電界により 変化させることができるとき, 系は強誘電性であるとい い, 系自身は強誘電体と呼ばれる。打ち消し合いが起こっ ている場合は反強誘電性, もともと永久双極子モーメン トがない場合は常誘電性であるという。

（福田敦夫）

\section{本 誌広告 料 金}

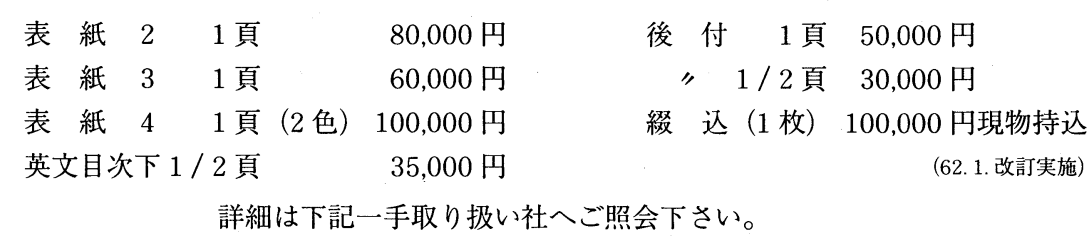

（株）共 栄 通 信 社

本 社 T 104 東京都中央区銀座 8-2-1（新田ビル） Tel. 03-572-3381 (代)

大阪支社 $=530$ 大阪市北区西天満 3-6-8（笹屋ビル） Tel. 06-362-6515（代） 